\title{
Identification of Strains of Citrus tristeza virus by Subtraction Hybridization
}

\author{
K. S. Derrick, M. J. Beretta, G. A. Barthe, and M. Kayim, Department of Plant Pathology, Citrus Research and \\ Education Center, IFAS, University of Florida, Lake Alfred 33850; and R. Harakava, Instituto Biológico, São \\ Paulo, SP, Brazil
}

\begin{abstract}
Derrick, K. S., Beretta, M. J., Barthe, G. A., Kayim, M., and Harakava, R. 2003. Identification of strains of Citrus tristeza virus by subtraction hybridization. Plant Dis. 87:1355-1359.

Citrus sudden death (CSD) appears to be a new disease that is a serious problem in Brazil. Symptoms of CSD include yellow stain in the phloem of the rootstock. The cause is not known, but it appears to be infectious and may only affect trees budded on Rangpur lime. In a survey in Brazil, in addition to CSD, we observed numerous trees on Rangpur lime that were obviously declining but had remained in production for several years. Trees with this disease, referred to as Rangpur lime decline (RLD) were different from those with citrus blight (CB). They had near-normal size fruit compared with the small fruit associated with $\mathrm{CB}$ and were negative in the serological test for the CB-associated protein (p12). Moreover, they did not have the yellow stain symptom and obviously were declining much more slowly than was reported for CSD. To determine what viruses or virus strains might be associated with CSD, double-stranded (ds)RNAs from fibrous roots of a tree with CSD and stem bark from greenhouse trees infected with Citrus tristeza virus (CTV) isolates T30 and T36 were used to make random primed cDNAs. A Clontech PCR-Select cDNA Subtraction Kit was used to subtract the CSD cDNA with cDNA from an equal mixture of dsRNA from T30 and T36. Of 28 clones that were sequenced, five were found to be significantly different from published CTV sequences. One clone (SDA-1) was found to be only $48 \%$ similar to CTV T30 based on amino acid sequence. Using samples collected in October 2001, hybridization assays with a DIG probe of SDA-1 were positive for RNA from roots of declining trees from an area where CSD is reported to occur and from a second area where trees were declining with what had been thought to be CB and are now considered to be RLD. The SDA-1 probe reacted weakly or not at all with RNA from stem bark of trees with CSD, collected in October 2001, or RNA from roots of trees that were declining with CB. Using samples collected in March 2003 from trees with severe decline (nearly dead), the SDA-1 probe reacted with all preparations from both stems and roots. Reactions to the SDA-1 probe also were observed in many stem or root samples from trees with RLD, with early symptoms of CSD, and nonsymptomatic trees. The SDA-1 probe did not react with samples from roots or stems of healthy or CB trees from Florida.
\end{abstract}

Additional keywords: Citrus limonia, C. sinensis, morte súbita dos citros, Poncirus trifoliata

A new disease that causes a rapid decline of citrus was first observed in 1999 in Comendador Gomes County, Minas Gerais State, Brazil (8). The decline appears to be spreading (1), and trees with similar symptoms are now seen in northern São Paulo State. Some affected trees decline rapidly within weeks of initial symptoms; thus, the disease is called citrus sudden death (CSD) or "morte súbita dos citros" (13). To date, approximately 3 million trees have been reported lost to CSD. A joint research ef-

Corresponding author: K. S. Derrick

E-mail: ksd@lal.ufl.edu

This research was supported by the Florida Agricultural Experiment Station and by a grant from the Florida Citrus Production Research Council.

GenBank Accession numbers of DNA sequences: AY242069 to 73 .

Accepted for publication 25 June 2003.

Publication no. D-2003-0908-02R

(C) 2003 The American Phytopathological Society fort between Fundecitrus, the Citriculture Center in Cordeirópolis, and universities supported by the Science and Technology Secretary of Research is addressing the CSD problem in Brazil.

CSD appears to affect only trees on Rangpur lime (Citrus limonia) $(1,8)$. About $85 \%$ of the trees in Brazil are on Rangpur lime; therefore, the threat of CSD is analogous to the decline of trees on sour orange (C. aurantium) that decimated the citrus industry in Brazil in the 1940s (3). Trees with CSD appear similar in some ways to those with citrus blight (CB), a disease of unknown cause that is responsible for the loss of approximately 10 million trees a year in Brazil (6). Both diseases cause a general decline with a significant reduction in fibrous roots. To determine if CSD is a variant of $\mathrm{CB}$, we made serological assays for the CB-associated protein (p12), a protein of unknown function (2) recently classified as a $\gamma$ expansin (12). The protein is present in high concentrations in leaves of trees with $\mathrm{CB}$, and serological assays for the protein are used to distinguish $\mathrm{CB}$ from other declines of citrus (5). The majority of the declining trees assayed in the CSD area were $\mathrm{p} 12$ negative.

For the past several years, the p12 assay has been used extensively to identify trees with $\mathrm{CB}$. In Florida, trees suspected to have $\mathrm{CB}$ invariably contain p12. In Brazil, it is not uncommon for declining trees on Rangpur lime, which is very susceptible to $\mathrm{CB}$, to be 12 negative (M. J. Beretta and C. B. Jesus, unpublished observations). During visits to Brazil, in addition to CSD, we observed numerous trees on Rangpur lime that were obviously declining, but had remained in production for several years. Trees with this disease, referred to as Rangpur lime decline (RLD), were different from those with $\mathrm{CB}$ and were in more temperate areas, in contrast to the hot climate where CSD has been reported. Trees with RLD had near-normal size fruit compared with the small fruit associated with $\mathrm{CB}$ and were negative in assays for $\mathrm{p} 12$. Moreover, they did not have the yellow stain symptom associated with CSD and were obviously declining much more slowly than was reported for CSD.

Based on symptoms and spread patterns, Bassanezi et al. (1) suggested that CSD may be caused by an insect-vectored pathogen, such as a new strain of Citrus tristeza virus (CTV), but acknowledged the difficulty of detecting a new strain of CTV with current serological and molecular probes. We report here an approach for detecting strains of known or unknown viruses in mixed infections and application of the method to the study of CSD.

\section{MATERIALS AND METHODS}

Sample collection sites. Comendador Gomes County, October 2001. Root, stem, and leaf samples were collected from trees with CSD in an advanced stage of decline.

Colômbia County, March 2003. Root, stem, and leaf samples were taken from 3.5-year-old trees that appeared healthy but had yellow bark symptoms and 2.5-yearold trees in an advanced stage of decline (nearly dead) with yellow bark symptoms. There were no healthy trees in the groves that were declining; therefore, samples of apparently healthy trees were taken from a grove of 1.5-year-old trees at a different location on the farm. All the trees were on Rangpur lime.

First location in Bebedouro County, October 2001. Root, stem, and leaf samples were taken from declining trees on Rangpur lime. This farm has a few trees on 
Rangpur lime randomly distributed in groves that are predominately on Cleopatra mandarin (C. reshni). Observations had been made for several years that the trees on Rangpur lime were declining, and it was assumed that this was due to CB. Trees on Rangpur lime are much more susceptible to $\mathrm{CB}$ than those on Cleopatra mandarin.

March 2003. Root, stem, and leaf samples were taken from declining trees on Rangpur lime and two apparently healthy trees on Cleopatra mandarin adjacent to a declining tree. The trees on Rangpur lime had been declining for several years, did not have yellow stain symptom, and were producing near-normal size fruit.

Second location in Bebedouro County, April 2002. Root, stem, and leaf samples were taken from a grove of 35-year-old trees on trifoliate orange (Poncirus trifoliata), which is very susceptible to $\mathrm{CB}$ and is reported to be resistant to CTV. The 10 declining trees assayed were p12 positive and had CTV in both stems and roots as determined by enzyme-linked immunosorbent assay (ELISA). The trees did not have yellow stain symptoms.

Third location in Bebedouro County, March 2003. Root, stem, and leaf samples were taken from a grove of 20-year-old trees on Rangpur lime with many trees declining with $\mathrm{CB}$. The trees did not have yellow stain symptoms.

Conchal County, March 2003. Root, stem, and leaf samples were taken from a grove primarily on sweet orange $(C$. sinensis) with some interplanting of trees on Rangpur lime. Most of the older trees on Rangpur lime were in a decline considered to be $\mathrm{CB}$, but declining trees on this farm had been checked previously for p12 and found to be negative. No yellow stain symptoms were observed, and the declining trees had near-normal size fruit. Samples from healthy-appearing trees were collected in a separate grove of 10-year-old trees on Rangpur lime.

Preparation of RNA. Total nucleic acid preparations from stem bark or fibrous roots were prepared by grinding with $2 \times$ STE (20 mM Tris-Cl, $0.2 \mathrm{M} \mathrm{NaCl}, 2 \mathrm{mM}$ EDTA [ph 8.0]), sodium dodecyl sulfate to

Table 1. Characteristics of Citrus tristeza virus (CTV) clones from roots of a tree with citrus sudden death

\begin{tabular}{lccc}
\hline Clone & Accession no. $^{\text {a }}$ & Comparisons to known sequences $^{\mathbf{b}}$ & Genomic region $^{\mathbf{c}}$ \\
\hline SDA-1 & AY242069 & $58 / 120$ AA 48\% T30 & $2080-2439$ \\
SDA-2 & AY242072 & $272 / 355$ N 76\% T385 & $5506-5860$ \\
SDA-3 & AY242070 & $192 / 234$ N 82\% T30 & $2681-2914$ \\
SDA-4 & AY242071 & $387 / 520$ N 74\% T30 & $7357-7876$ \\
SDA-5 & AY242073 & $305 / 350$ N 87\% T385 & $9176-9525$ \\
\hline
\end{tabular}

${ }^{a}$ GenBank accession numbers of DNA sequences.

${ }^{\mathrm{b}}$ Number of matches/total; $\mathrm{AA}=$ amino acid and $\mathrm{N}=$ nucleotide; percent similarity to nearest strain.

${ }^{\mathrm{c}}$ Based on nucleotide sequence of nearest strain.

d Accession number: AF260651.

e Accession number Y18420.

${ }^{\mathrm{f}}$ The first 179 nucleotides of SDA-5 are $99 \%$ similar to a partial CTV sequence: GenBank AJ399531.

$2 \%$, and one-half volume of phenol was added. After shaking for $30 \mathrm{~min}$ at room temperature, the mixture was centrifuged, and the water phase was collected and kept at $4^{\circ} \mathrm{C}$ or frozen at $-20^{\circ} \mathrm{C}$ for further use. Double-stranded (ds)RNA was prepared as described by Dodds et. al. (7). Total RNA was prepared using an RNeasy Plant Mini Kit (Qiagen, Valencia, CA) starting with tissue or ethanol-precipitated total nucleic acid preparations.

Polymerase chain reaction-select cDNA subtraction. dsRNAs from $1 \mathrm{~g}$ of fibrous roots taken from a tree in Comendador Gomes County with CSD, and from $1 \mathrm{~g}$ of an equal mixture of stem bark from trees infected with CTV isolates T30 and T36, maintained in a greenhouse in Florida, were suspended in $5 \mu$ of water and used to make cDNAs. Subtraction hybridization and polymerase chain reaction (PCR) were done using a Clontech PCRSelect cDNA Subtraction Kit (Clontech, Palo Alto, CA) as described, with the exception that the dsRNA was heated at $99^{\circ} \mathrm{C}$ for $3 \mathrm{~min}$ before first-strand synthesis using random primers. The subtracted cDNA was cloned using a T/A pGEM Teasy Vector System II Kit (Promega Corp., Madison, WI). Plasmids were prepared from cultures of selected colonies using a QIAprep Spin Miniprep Kit (Qiagen). DNA sequencing was done by the University of Florida Sequencing Core Facility, Gainesville. Sequences were compared using the NCBI database with BLAST. Alignments and analyses were performed using Clustal X (ver. 1.81) and Genedoc (ver. 2.6.002).

Hybridization assays. Digoxigenin (DIG)-labeled probes were prepared using a PCR DIG Probe Synthesis Kit (Roche, Mannheim, Germany) using nested primers 1 and 2R from the Clontech PCR-Select cDNA Subtraction Kit and clones SDA-1 through 5 (Table 1). A DIG probe to detect all strains of CTV was prepared using PCR with forward and reverse CP36 primers (10) and a cDNA clone of the coat protein gene of CTV T30. Total RNA preparations were applied to charged nylon using a dot blotter as described by Sambrook and Russell (15). Each spot of RNA was from ap- proximately $40 \mathrm{mg}$ of fresh weight tissue. DIG Easy Hyb solution (Roche) was used for hybridizations with a $50^{\circ} \mathrm{C}$ hybridization and a $68^{\circ} \mathrm{C}$ high-stringency wash. Chemiluminescent detection of the DIG probe was done using antidigoxigenin-AP Fab fragments and CSP-Star obtained from Roche.

Serological assays. Assays for the CBassociated protein (p12) using a monoclonal antibody were as previously described (5).

\section{RESULTS}

To determine if CSD is related to $\mathrm{CB}$, leaf samples from trees with CSD were collected for serological assays for $\mathrm{p} 12$. Of 76 leaf samples collected from trees with CSD from groves in Comendador Gomes and Colômbia Counties, only 7 were positive for $\mathrm{p} 12$, indicating no consistent association of CSD with $\mathrm{CB}$, but that some trees appeared to have both CSD and CB.

Of 28 clones from the subtraction experiment that were sequenced, 5 were found to be significantly different from published CTV sequences (Table 1). Clone SDA-1 had a $48 \%$ similarity to strain T30 based on the amino acid sequence predicted by nucleotides 2,088 to 2,442 . The nucleotide sequence of SDA-2 was $76 \%$ identical to cDNA of CTV strain T385. Clones SDA-3 and -4 were 83 and $74 \%$ identical, respectively, to cDNA of CTV strain T30. Clone SDA-5 was $87 \%$ identical to T385, but the first 179 nucleotides of the clone were $99 \%$ identical to a partial sequence of a strain of CTV from Australia (GenBank no. AJ399531). An additional 21 clones were 93 to $99 \%$ similar to published CTV nucleotide sequences; one clone had no insert and one clone appeared to be unknown (a DIG probe from this clone did not hybridize with any of the samples). There were no duplicate clones.

Using samples collected in October 2001, the DIG probe prepared using clone SDA-1, hybridized with RNA from roots of trees with CSD in severe decline from a grove in Comendador Gomes County and declining trees from the first location in Bebedouro County (Fig. 1A). Of the 10 root samples from trees on Rangpur lime, 7 gave strong reactions and 3 gave weak ones. The trees from the first location in Bebedouro County had been assumed to be declining to $\mathrm{CB}$, but only two of five trees assayed were p12 positive. Leaves from four additional declining trees on Rangpur lime in this grove were also p12 negative. RNA from roots of two trees with CB (p12 positive) on trifoliate orange, collected at a second location in Bebedouro County in April 2002, and RNA from stems of three trees with CSD, hybridized very weakly or not at all with the SDA-l probe. There was no reaction to RNA samples from roots or stems of trees from Florida (Fig. 1A and 2). Eight additional samples, four from roots and four from stems of two trees with 
$\mathrm{CB}$ and two that appeared healthy, also were negative (results not shown).

Results similar to those from using the SDA-1 probe were observed with some samples using a DIG probe from SDA-3, except that the weak reactions were a little stronger (Fig. 1B and not shown). This possibly was due to cross reactions to other strains of CTV, because SDA-3 has considerable homology to published CTV sequences. DIG probes made to SDA-2, -4 , and -5 gave results similar to those with the SDA-3 probe (not shown). Using samples collected in March 2003, the SDA-1 probe reacted with all stem and root samples from trees with severe decline (nearly dead) due to CSD (Fig. 2). In addition, there were reactions with many samples from stems or roots from healthy-appearing trees, trees with early symptoms of CSD, and trees with RLD. Some samples from healthy-appearing trees on sweet orange and Cleopatra mandarin adjacent to declining trees on Rangpur lime also hybridized with the SDA-1 probe. RNA from

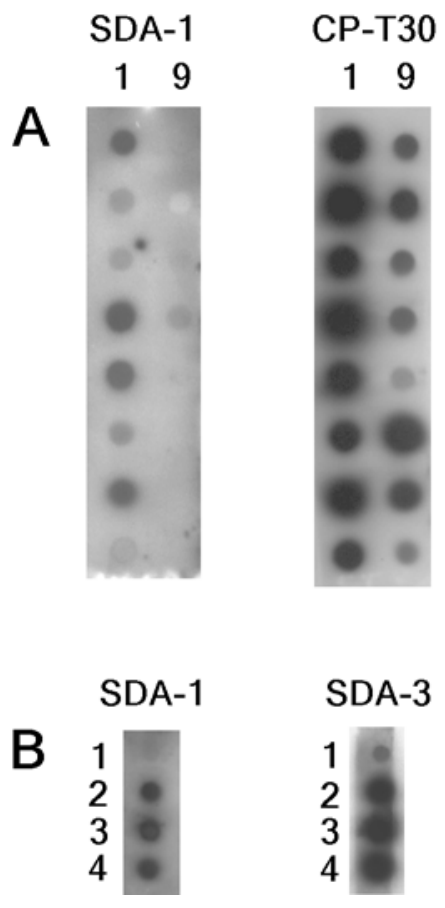

Fig. 1. Duplicate membranes from samples collected October 2001 and April 2002 probed with A, SDA-1 and CP-T30 and B, SDA-1 and SDA-3. A, Samples were spotted in columns of eight with the number of the first sample in each column shown at the top; 1-10 on Rangpur lime, 11-12 on trifoliate orange, and 13-16 on rough lemon; $1-7,11-13$, and $15-16$ from roots; $8-10$ and 13 from stems; $1-4$, trees with Rangpur lime decline (RLD) from first location in Bebedouro County; 5-10, trees with citrus sudden death (CSD) from Comendador Gomes County; 11-12, trees with citrus blight (CB) from second location in Bebedouro County; 13-16, trees from Florida 13, 15-16 with CB, 14 apparently healthy. B, Samples 1-4 on Rangpur lime; 1 from stems, 2-4 from roots; 1 and 3-4, trees with CSD from Comendador Gomes County; 2, tree from first location in Bebedouro County with RLD. roots of a small tree on Rangpur lime that had been inoculated by root grafting with roots from a tree with CSD hybridized strongly with both the SDA-1 and CP-T30 probes.

Using duplicate membranes with a DIG probe made to the coat protein gene of CTV-T30 (CP-T30), which should hybridize with all strains of CTV, all the samples from grove trees were positive, including samples from roots of trees on trifoliate orange and one from Carrizo citrange $(P$. trifoliate $\times C$. sinensis) roots (Figs. 1A and
2). Samples from greenhouse-grown seedlings, which should be free of CTV, did not hybridize with the SDA-1 or CP-T30 probes. (Fig. 2).

\section{DISCUSSION}

The declining trees observed in Comendador Gomes and Colômbia Counties had symptoms described for CSD, including a yellow stain in the phloem of the rootstock and production of near-normal size fruit. Trees with CSD have been reported primarily in Minas Gerais State and the most

\section{SDA-1}

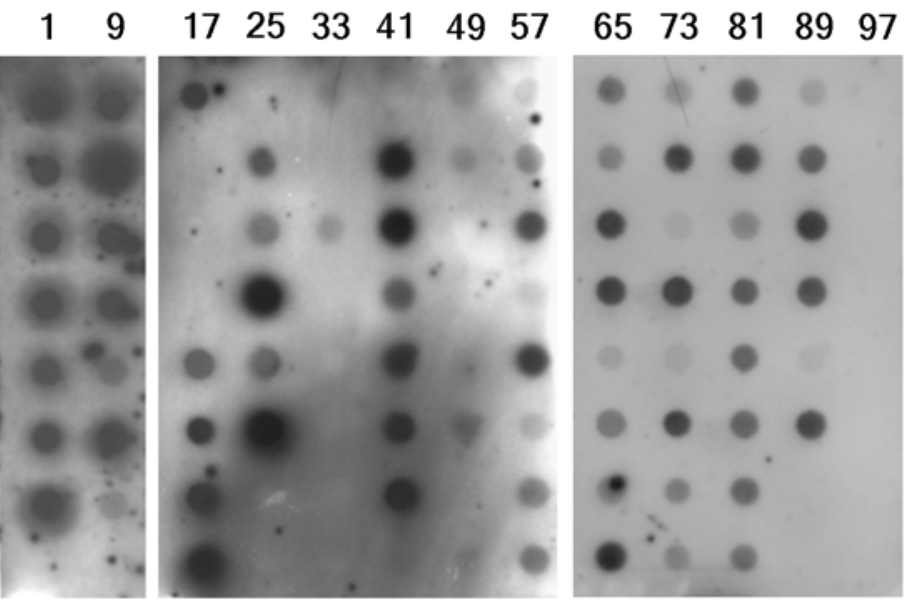

\section{CP-T30}

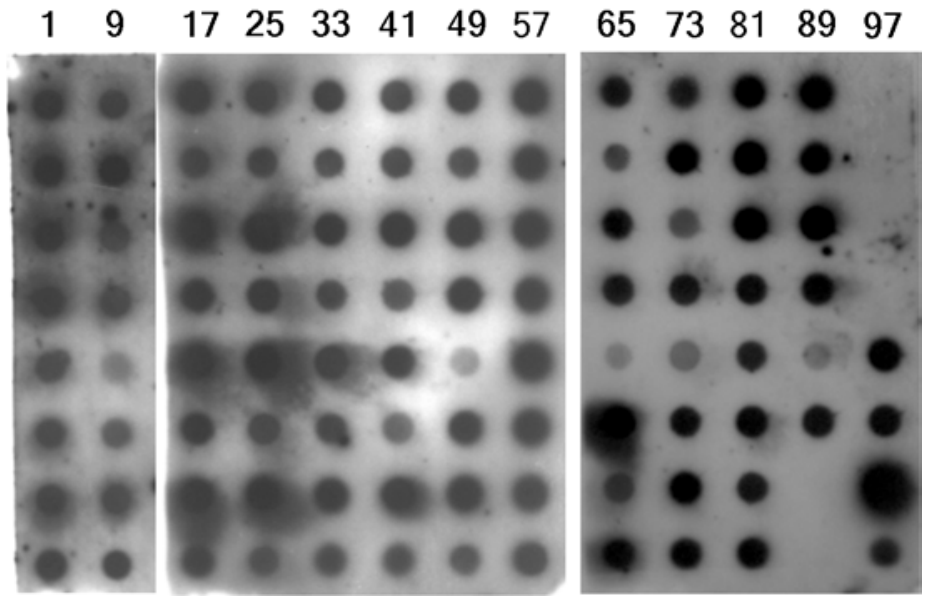

Fig. 2. Duplicate membranes from samples collected in March 2003 probed with SDA-1 and CPT30. Samples were spotted in columns of eight with the number of the first sample in each column shown at the top. Except where noted, the samples were from trees on Rangpur lime from Brazil. Samples 1-48 (except 8 and 16) were from Colômbia County; 1-7 from stems and 9-15 from roots of trees with severe citrus sudden death (CSD) and 8 and 16 from roots of healthy trees on Carrizo citrange from Florida. Samples 17-94 were from stems (odd numbers) followed by roots (even numbers) from the same tree; 17-32, healthy-appearing trees with no yellow bark symptoms; 33-48, trees in early decline with yellow bark symptoms. Samples 49-64 were from a location in Conchal County; 49-54, trees with Rangpur lime decline (RLD); 55-58, healthy-appearing trees on sweet orange; 59-64, healthy-appearing trees. Samples 65-78 were from the third location in Bebedouro County; 65-74, declining trees and 75-78, healthy-appearing trees. Samples 79-92 were from the first location in Bebedouro County; 79-84 and 89-90, trees with RLD; 85-88 and 91-92, healthyappearing trees on Cleopatra mandarin; 93-94, 1-year-old tree root grafted with roots from a tree with CSD; 95-100, from stems of 1-year-old seedlings from a greenhouse in Florida; 101-102, from stems from trees on rough lemon from Florida; 103 from stems and 104 from roots from a tree with citrus blight on Carrizo citrange from Florida. 
northern parts of Sao Paulo State, where year-round temperatures are hot, a climate not recognized as optimal for citrus production. The trees with RLD observed in Bebedouro and Conchal Counties are in more temperate regions of Sao Paulo State. Trees with RLD had near-normal size fruit, in contrast with the small fruit associated with $\mathrm{CB}$, and were kept in production even though they had thin canopies. On the farm in Conchal County, essentially all of the 20-year-old or older trees on Rangpur lime were in some stage of decline. Declining trees were reportedly only removed when they produced less than about $140 \mathrm{~kg}$ of fruit. The declining trees that we examined on this farm did not have yellow stain symptoms and were p12 negative. The farm manager stated he had also failed to observe yellow stain symptoms in declining trees.

The causes of CSD and RLD are not known, but they are in some ways similar. Both diseases appear to specifically cause a general decline of trees on Rangpur lime. We observed many healthy-appearing trees on sweet orange and Cleopatra mandarin next to trees on Rangpur lime that were declining with RLD, and there have been no reports of CSD on rootstocks other than Rangpur lime $(1,8)$. The causes of RLD and CSD could be entirely different, or possibly caused by the same or related infectious agents, with RLD being a milder form of CSD. CSD may not be a new disease, but only the expression of symptoms associated with RLD when trees on Rangpur lime are grown in a hot climate. The citrus industry in Brazil has only recently moved north into Minas Gerais State with large plantings on Rangpur lime. Based on fruit size and p12 assays, RLD and CB appear to be different diseases, although they both cause a similar general decline of affected trees. Trees on all rootstocks can be affected by $\mathrm{CB}$, but some rootstocks appear to have "field resistance" to $\mathrm{CB}$. Losses to $\mathrm{CB}$ of trees on sweet orange are much less than on more $\mathrm{CB}$-susceptible rootstocks such as Rangpur lime. It is not known how many of the estimated 10 million trees (most of which are on Rangpur lime) reported to be lost per year to CB (6) are actually declining due to RLD. Because the causes of CB and RLD are not known, they can be differentiated only by 12 assays and, possibly, by fruit size. There are very few trees on Rangpur lime in Florida, but $\mathrm{CB}$ is a serious problem in the state on trees grown on CB-susceptible rootstocks. In Florida, there is a good correlation between trees declining on $\mathrm{CB}$ susceptible rootstocks and the presence of p12.

The SDA-1 strain was found in all trees in an advanced stage of CSD. The SDA-1 strain also was found in many stem or root samples trees in an early stage of decline with CSD, in trees with RLD, and in healthy-appearing trees, including some on
CSD-tolerant rootstocks. Trees on rootstocks tolerant to CSD, whether it is caused by a strain of CTV or some other infectious agent, may serve as sources of inoculum when they are grown near trees on Rangpur lime. The demise of sour orange as a rootstock in Florida was accelerated by planting trees on tolerant rootstocks next to blocks of trees on sour orange. In some cases, the tolerant rootstocks even were used as replants in groves on sour orange, and most of the budwood used on sour orange was propagated on tolerant rootstocks.

Using a non-strain-specific probe, $\mathrm{CP}$ T30, most of the trees from Brazil that were assayed appeared to be uniformly infected with CTV, with time of year and locations within a tree having little effect on the virus titer. In contrast, there was a wide variation in the titer of the SDA-1 strain at different times of the year and the strain frequently was distributed unevenly in a tree.

Finding the SDA-1 strain in all trees in an advanced stage of decline is suggestive, but certainly does not prove the strain causes CSD. Rather than establishing a strain of CTV as the cause of CSD, perhaps we have only highlighted a difficulty in associating a strain of CTV with a disease. Citrus trees commonly are infected with a mixture of strains of CTV $(9,11)$, but assays with non-strain-specific probes, such as DIG probe CP T30, fail to detect the effects that time of year and degree of disease development may have on the titer and distribution of a specific strain within a tree. Variations in virus titer such as we observed with the SDA-1 strain probably occur with other strains. This might be expected when a number of mild strains, which may have some capacity for cross protection, and disease-causing strains are competing for infection sites in the same tree. The titer of strains that cause decline of trees on sour orange in Florida were shown to be suppressed by mild strains of CTV by serology (14).

It is difficult to obtain biologically pure strains of CTV and to establish which strain is responsible for a given disease. Probably the only way to confidently fulfill Koch's postulates with a strain of CTV is with an infectious clone. This has been done only with the Florida sour orange decline isolate T36 (16). Inoculations with an infectious clone probably will be necessary to prove that a strain of CTV causes CSD.

Detection of CTV in trifoliate orange roots and Carrizo citrange may appear unexpected, because they are reported to be resistant to CTV (4). In our studies on the cause of $\mathrm{CB}$, strains of CTV similar to $\mathrm{T}-30, \mathrm{~T}-36$, and VT were detected consistently in roots of Carrizo citrange and trifoliate orange by reverse transcriptase (RT)PCR, by cloning and sequencing clones from dsRNA preparations, ELISA, and hybridization. It is not known if CTV is replicating in the resistant roots or merely moving down from the infected scion. Perhaps replication is indicated by observations that the CTV titer in some root samples approaches that found in the scion.

The Clontech PCR-Select cDNA Subtraction Kit with modifications for use with dsRNA should have application in obtaining virus sequences from other plants suspected to be infected with a mixture of viruses and in further studies on strains of CTV. The method has the advantage of looking for viruses and virus strains without the bias associated with serology or RT-PCR. The five clones reported in this study were from the more variable $5^{\prime}$ end of the viral genome, suggesting that the method works well for strains with considerable variation in that region, but may not differentiate sequences on the more conserved $3^{\prime}$ region. There were no duplicates in the 28 clones that were sequenced in this study, indicating considerable depth to the library; therefore, additional strains of CTV and possibly other RNA viruses may be detected by sequencing additional clones.

\section{ACKNOWLEDGMENTS}

We thank L. F. Girotto for helpful discussions and assistance in collecting samples, N. A. R. Peres, A. J. Ayres (FUNDECITRUS), and E. S. Stuchi (EMBRAPA) for help with sample collection, C. B. Jesus for p12 analyses, M. G. H. Dekkers for assistance with ELISA, and S. Shanker and the staff of the ICBR DNA sequencing facility for sequencing.

\section{LITERATURE CITED}

1. Bassanezi, R. B., Filho, A. B., Amorim, L., Gimenes-Fernandes, N., Gottwald, T. R., and Bove, J. M. 2003. Spatial and temporal analyses of citrus sudden death as a tool to generate hypotheses concerning its etiology. Phytopathology 93:502-512.

2. Ceccardi, T. L., Barthe, G. A., and Derrick, K S. 1998. A novel protein associated with citrus blight has sequence similarities to expansin. Plant Mol. Biol. 38:775-783.

3. Costa, A. S. 1956. Present status of tristeza disease of citrus in South America. FAO Plant Prot. Bull. 4:19-27.

4. Deng, Z., Huang, S., Xiao, S. Y., and Gmitter, F. G., Jr. 1997. Development and characterization of SCAR markers linked to the citrus tristeza virus resistance gene from Poncirus trifoliata. Genome 40:697-704.

5. Derrick, K. S., Barthe, G. A., Hewitt, B. G., Lee, R. F., and Albrigo, L. G. 1992. Detection of citrus blight by serological assays. Proc. Fla. State Hortic. Soc. 105:26-28.

6. Derrick, K. S., and Timmer, L. W. 2000. Citrus blight and other diseases of recalcitrant etiology. Annu. Rev. Phytopathol. 38:181-205.

7. Dodds, J. A., Jarupat, T., Lee, J. G., and Roistacher, C. N. 1987. Effects of strain, host, time of harvest, and virus concentration on doublestranded RNA analysis of citrus tristeza virus. Phytopathology 77:442-447.

8. Gimenes-Fernandes, N., and Bassanezi, R. B. 2001. Doença de causa desconhecida afeta pomares cítricos no norte de São Paulo e Sul do Triângulo Mineiro. Summa Phytopathol. 27:93.

9. Grant, T. J., and Higgins, R. P. 1957. Occurrence of mixtures of tristeza virus strains in cit- 
rus. Phytopathology 47:272-317.

10. Hilf, M. E., and Garnsey, S. M. 2000. Characterization and classification of citrus tristeza virus isolates by amplification of multiple molecular markers. Pages 18-27 in: Proc. 14th Conf. Intl. Org. Citrus Virol. P. Moreno, J. V. da Graça, and L. W. Timmer, eds. University of California, Riverside.

11. Hilf, M. E., Karasev, A. V., Albiach-Marti, M. R., Dawson, W. O., and Garnsey, S. M. 1999. Two paths of sequence divergence in the citrus tristeza virus complex. Phytopathology 89:336-342

12. Li, Y., Darley, C. P., Ongaro, V., Fleming, A., Schipper, O., Baldauf, S. L., and McQueen-
Mason, S. J. 2002. Plant expansins are a complex multigene family with an ancient evolutionary origin. Plant Physiol. 128:1-11.

13. Muller, G. W., De Negri, J. D., Vildoso, C. I. A., Mattos, D., Jr., Pompeu, J., Jr., Teófilo Sobrinho, J., Machado, M. A., Carvalho, S. A., and Girotto, L. F. Citrus sudden death: a new disease of citrus in Brazil. Proc. 15th Conf. Int. Org. Citrus Virol. J. V. da Graça, N. Duran, and B. Milne, eds. University of California, Riverside. In press.

14. Powell, C. A., Rundell, P. A., and Pelosi, R. R. 2003. Suppression of decline-inducing isolates of citrus tristeza virus by nondecline-inducing isolates. HortScience 38(1):62-64.
15. Sambrook, J., and Russel, D. W. 2001. Molecular Cloning: A Laboratory Manual. 3rd ed. Cold Spring Harbor Laboratory Press, Cold Spring Harbor, NY

16. Satyanarayana, T., Bar-Joseph, M., Mawassi, M., Albiach-Marti, M. R., Ayllon, M. A. Gowda, S., Hilf, M. E., Moreno, P., Garnsey, S. M., and Dawson, W. O. 2001. Amplification of citrus tristeza virus from a cDNA clone and infection of citrus trees. Virology 280:87-96.

17. Tucker D. P. H., Lee R. F., Timmer, L. W Albrigo, L. G., Brlansky, R. H. 1984. Experimental transmission of citrus blight. Plant Dis. 68:979-80. 